\title{
The place of machine parts production in the restructuring Bulgarian industry
}

\author{
Aneta Deneva ${ }^{1}$ \\ ${ }^{1}$ D. A. Tsenov Academy of Economics, 5250, Svishtov, Bulgaria
}

\begin{abstract}
The end of the 20th century was quite stormy and left its mark in all fields of human existence. Moreover, it faced the human race with new challenges and trials. One of them is the wholly change in the economic system of society. The Bulgarian economy was also not pass of such changes. They were accompanied by large and painful transformations and turbulence. One of the most affected areas was industrial production. Its restructuring, the emergence and overcoming of various asymmetry continues to this day. At the present time, when we talk about the "new Industrial Revolution", the digitization of the processes in the economy, when the world switched to Industry 4.0 the problem with the construction of a modern and competitive industrial sector is even more topical. An important part of this sector is the "machine parts production" industry. Over the years it also underwent a number of dips and transformations, but managed to maintain its position and lead role in the Bulgarian industry.
\end{abstract}

\section{Introduction}

The industry is a major and traditional branch of the Bulgarian economy. Usually its beginning is associated with the creation of the first factories in Bulgaria after 1834.In the historical archives, however, significantly earlier information about the existence of "industrial" activities in Bulgarian lands is revealed [1]. Already in the distant 1348, a special category of countryman was formed, called "Technikari", which lay the foundations of the craft production. This is a reason to assume that the emergence of industrial activities and in particular the Bulgarian industry occurs in the early Middle Ages. It is undisputed that for actual industrial production it can only be spoken after 1878 .

With the accepting the law of "The encouragement of the local industry" in 1892, the Bulgarian industrial production start officially. Since then a certain share in it has been the production of iron and metal products, which is the progenitor of machine parts production industry as a branch of the Bulgarian industry.

For the business historians the first steps were made in 1839 and are related to the construction of machines for the first textile factory in Bulgaria - Sliven [2]. Since then it is an important branch of the Bulgarian industry. In the period up to the First World War its development rates was too slow [3]. The militarization of the economy accelerates them at the end of 1918. The state policy of promoting industrial production also has a positive impact as a result of which the number of machine Enterprises is substantially increased. 
According to the data at the report of the International Commission on investigation, the causes and conduct of the Balkan wars of the International Peace Foundation-Carnegie [4] during the period $1909-1912,18$ metal processing enterprises and 1 shipbuilding company from a total of 102 encouraged enterprises in the whole economy were promoted in Bulgaria.

The country's unfavorable peace pact, sanctions and reparations, and the global economic crisis 1920-22, have a negative impact on the development of Bulgarian machine parts production industry. Overall, for the period from 1834 to 1939 , it can be argued that it does not play a significant role in the development of the Bulgarian industry. The number of machine companies reached only 94 in 1934 and they created $2.4 \%$ of the country's industrial production [5].

In the years since then, the development rates of the machine parts production sector have significantly changed and it has attained a leading role in the Bulgarian industry. It has invested considerable resources. During this period were built a number of machine enterprises for hydraulic equipment, agricultural machinery, etc.

In the beginning of the 70 years at the rates of development, machine-building and metalworking significantly overtake the other branches of the economy. Then the main centers of the machine building were created in Ruse and Radomir and the relative share of the construction equipment production in the total volume of production reaches $22.9 \%$. Leading in the sector structure of the Bulgarian industry become machine-building, metalworking, electrical engineering and electronic industries.

By the end of the 70 years on some of the main indicators per capita these branches ranked 20th and 30th in the world, and in the production of electric and forklift trucks, electric hoists and other complex equipment our country is in the first ten [4]. Machine Enterprises produced $43.6 \%$ of the country's total production at the end of the 80 years.

The data are reason the years from 1878 to 1987 to be defined as the period of birth and validation of the Bulgarian machine building. This is perfectly in accordance with the development of our industry as a whole. It is clear that during these years industrial production gradually reached the leading positions in the national economy and Bulgaria was transformed from agrarian into an industrial state.

After 1989, the Bulgarian economy is distinguished by the presence of disproportions, manifested in [1]:

1. Divergence between the production facilities and the capacity of the raw energy base.

2. Imbalance between the general industrial level of the country and the Technical and economic parameters of the manufactured products.

3. Discrepancy between export opportunities and import needs.

They put a questionof restructuring of the economy in order to reduce the share of losing, resource-intensive enterprises and industries, privatizing part of the built production facilities, ensuring a level playing field between different Types of property, etc. In the beginning of the 90 years, the first attempts were made to outline its main guidelines, as in parallel the question arises for the realization of a change in the general structure of the national economy. Part of Bulgarian economists raise the thesis for the return of the leading role of the agrarian sector, while others emphasize the need to transform the services sector into a leading. A major overhaul of the place and role of the industrial production in the Bulgarian economy and its future development is very rightly necessary.

The restructuring of industrial production was accompanied by a number of problems, the solution of which necessitated the privatization and restructuring of ownership in the industrial sector; Create a new regulatory framework for industrial production and organizational restructuring; Change in the structure and number of employees; Restructuring, etc. In line with it is formulated a new innovative and investment strategy in the industry and begin to build a new internal sector structure of the Bulgarian industry. 
The process of this construction was quite lengthy and controversial. It has led to substantial changes in the place and role of individual industry sectors and in particular mechanical engineering. Innovativeness of the economy is also of great importance for economic growth $[6,7,8]$.

\section{Transformations in the sector structure}

Transformations in the sector structure can be explored using different indicators. Some of them are dynamics of the total production of the various sectors, changes in the number of people employed, changes in the total number of enterprises, etc. The most common among them is the change in the relative share of the total industrial production. In the case of general industrial production, the totality is understood [1]:

1. Returns from sales of finished goods produced.

2. Change (increase or decrease) in stocks of finished products at the end of the reporting period.

3. Manufactured fixed assets for own use.

4. The value of services from tolling work - the special in the case is that the value of the service and the value of the materials of the clients is included.

5 . Value of the basic repair for own production.

6. Alteration of the residues of work in progress in the main production and semimanufactured own production.

The impact of the indicator on the financial performance of business structures is associated with the change of relative-fixed costs. It is also a factor in determining the cash inflows of enterprises. The analysis of the sector structure through the dynamics of the general industrial production is carried out by means of indices of industrial production based on the current sectoral classifications.

In 1989, which was adopted as the start of the restructuring process, the national sector structure included a total of 18 industrial industries. Among them are the leading machinebuilding, electrical engineering and electronic industry with a share of $32.8 \%$ in the overall structure of the industrial production. During the period 1989-1993, the growth rate of the industrial sector was the strongest. In 1993 was reached the lowest point of development of industrial production- it was only $51.5 \%$ of this in 1989 . These negative processes are reflected in the sector structure of industrial production $[9,10]$. Clearly outlined is the negative trend in the development of almost all industries. At that time our country lost its leading positions in the field of electrical engineering and electronics industry, mechanical engineering and metalworking, whose share fell to $5.9 \%$ for the electrical and electronic industries respectively, $9 \%$ for Metal processing, $14.9 \%$ for mechanical engineering.

Despite the start of the privatization and restructuring processes, the years 1993-96 are one of the hardest for the Bulgarian industry and for the machine parts production industry in particular. That is when the closure of many losing enterprises, the work of entire industries and sectors is suspended, in a crisis fall the largest and most significant economic structures for the country. This is reflected in the indices of the general industrial production. The share of mechanical engineering, electrical engineering and electronic industries declined respectively to $9.1 \%$ and $4.9 \%$.

The introduction of the currency board in 1997 accelerated the process of restructuring. The consequences of this are reflected in the stabilization of macroeconomic indicators observed in 2000 and overcoming the negative tendencies in certain important activities for our country, one of which is machine parts production industry.

Since 2001, the process of preparing for incorporation to the European Community and industrial production policy has been fully subordinated to the European requirements and 
the European legislation. This is reflected in a significant change in the sector structure of industrial production. Unfortunately, the share of mechanical engineering, electrical engineering and electronic industries has been sharply reduced. Positive changes are only in the manufacture of metal products. Even the established stabilization of industrial production is not accompanied by the increase in the relative share of the machine building in the total production volume. The reasons for this negative result are complex. They are related both to the significant technological and technical backlog and to the need to develop and implement new strategies, policies and mechanisms for the development of competitive advantages in different sectors [11].

Only after 2010 were accomplish changes in the sector structure, manifested in the increase in the relative share of the production of machines and equipment $-3.2 \%$ and the production of electrical equipment $-3.0 \%$. Only two years later, in 2012, the Engineering accounts for $7.9 \%$ of the total industrial production of the manufacturing industry. However, this is about 4 times less than the 1988 volumes. After 2015, although a slow relative share of machine building grew in the total volume of industrial production. According to the Ministry of Economy data [12] in 2016 the increase compared to the previous year was $2.2 \%$ and in $2017,14.8 \%$.

In the history of the Bulgarian industry the machine parts production industry has its permanent place (Fig. 1).

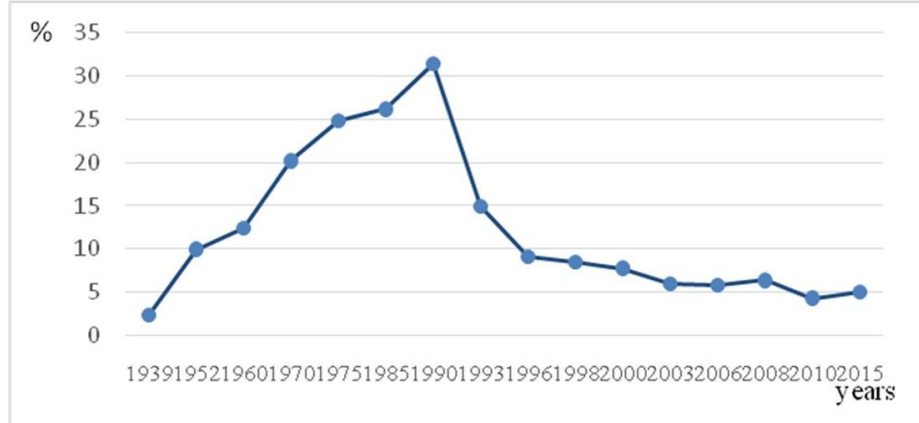

Fig. 1. The place of machine parts production industry in the Bulgarian industry

Regardless of the surviving transformations and turbulence, it remains one of its main foundations. As evidenced by the figure after 2003, the mechanical production is a relatively stable part of the Bulgarian industry. After 2015, his positive trade [13] continued to this day. Bulgarian engineering production is realized in countries from all continents. The industry provides employment for 129370 people and generates about $10 \%$ of GDP [13].

\section{Conclusion}

The restructuring of the Bulgarian industry, the emergence and overcoming of various asymmetry in it is a continuous and dynamic process. This process to a degree is also deterministic by the state-led industrial policy. Nowadays, when the calls for a "new industrial revolution" are increasingly heard, the problem of the structure, rates of development and technological base of modern industrial production is even more topical [14]. Also using modern methods in business management that contribute to their market success $[15,16]$. Its resolution depends both on the "good will" of the Bulgarian governments and on the knowledge, skills and scale of the thinking of the Bulgarian 
industrial entrepreneurs. Pooling their efforts is a precondition for building a sustainable, dynamic and competitive industrial sector. An important factor is also supporting the innovativeness of enterprises. Their market success translates into the growth of the entire economy $[20,21]$.

\section{References}

1. A. Deneva, Svishtov: Tsenov Academic Publishing, 34, 64, 22 (2013)

2. I Haralampev, S.I. Jordanov, Mechanical Engineering in Bulgaria - past, present and future (Sofia: Technics, 1982)

3. V. Hristova, Entrepreneurship - Theoretical foundations and practical dimensions (Abagar, V. Tarnovo, 2013)

4. Report of the International Commission to Inquire into the Causes and Conduct of the Balkan Wars https://archive.org/details/reportofinternat00inteuoft/

5. N. Nikolov, E3S Web of Conferences, 105, 04015 (2019) https://doi.org/10.1051/e3sconf/201910504015.

6. M. Petrova, M. Tepavicharova, L. Dikova. E3S Web of Conferences, 41, 04017 (2018) https://doi.org/10.1051/e3sconf/20184104017.

7. V. Koval, G. Duginets, O.lekhanova, A. Antonov, M. Petrova, Entrepreneurship and Sustainability, 6(4), 1922 (2019) http://doi.org/10.9770/jesi.2019.6.4(27)

8. A. Deneva, Narodnostopanski arhiv, 3, 79 (2010)

9. N. Kurmanov, M. Petrova, S. Suleimenova, E3S Web of Conferences, 105, 04045 (2019) https://doi.org/10.1051/e3sconf/201910504045.

10. Pukala, R.; Petrova, M. E3S Web of Conferences, Vol. 105, 04034 (2019) https://doi.org/10.1051/e3sconf/201910504034.

11. Manufacture of machinery and equipment n.e.c. (C28). www.mi.government.bg/bg/themes/sektor-proizvodstvo-na-mashini-i-oborudvane-sobshto-i-specialno-prednaznachenie-s28-527-276.html

12. Mechanical Engineering: Upward trend continues. https://www.capital.bg/specialni_izdaniia/tejka_industriia/2018/10/19/3329823_mashi nostroeneto_vuzhodiashtiiat_trend_produljava/

13. Strategy for the digital transformation of the Bulgarian industry (Industry 4.0), https://www.mi.government.bg/files/useruploads/files/ip/kontseptsia_industria_4.0.pdf

14. Ivanov, D. From ninth to tenth. Sofia (2004)

15. I. Gryshova, M. Petrova, M. Tepavicharova, A. Diachenko, T. Gutsul, Entrepreneurship and Sustainability, 7(1) $690 \quad$ (2019) http://doi.org/10.9770/jesi.2019.7.1(49).

16. T. Odinokova, M. Bozhinova, M. Petrova, E3S Web Conferences, 41, 04015 (2018) https://doi.org/10.1051/e3sconf/20184104015

17. A. Deneva, London Review of Education and Science, 1, 128 (2016)

18. United Nations Industrial Development Organization (Demand for Manufacturing: Driving Inclusive and Sustainable Industrial Development, Vienna, 2018).

19. R. Pukala, Engineering Management in Production and Services, 8, 3, 43 (2016)

20. V. Zahars, M. Stivrenieks, Journal of Security and Sustainability, 7 (4), 643 (2018) https://doi.org/10.9770/jssi.2018.7.4(3) 